\title{
Home range and habitat selection of captive-bred and rehabilitated cape vultures Gyps coprotheres in southern Africa
}

\author{
Ben Jobson, Kerri Wolter, Lara Jordan \\ Ara Monadjem and J. Marcus Rowcliffe
}

\begin{abstract}
Following the continual decline of the Cape vulture Gyps coprotheres since the 1960s, captive breeding and rehabilitation programmes have been established to reinforce populations across southern Africa. This study examines the spatial ecology of captive-bred and rehabilitated vultures following release. Our analysis used 253,671 GPS fixes from 20 captive-bred and 13 rehabilitated birds to calculate home range sizes using kernel density estimation. We found that home range size did not differ significantly between captive-bred and rehabilitated birds. The location of home ranges differed: captive-bred birds showed greater site fidelity, remaining close to their release site, whereas rehabilitated birds dispersed more widely across the species' native range. By remaining close to their release site within a protected area, captive-bred birds had a significantly higher per cent of their GPS fixes within protected areas than did rehabilitated birds. Despite fidelity to their release site, captive-bred birds demonstrated innate capabilities for natural foraging behaviours and the same habitat selection strategy as rehabilitated individuals. These findings suggest that captive breeding and reinforcement of populations at declining colonies could provide localized benefits. Future long-term studies should seek to analyse survivorship and identify the breeding behaviour of these captive-bred birds once they reach sexual maturity.
\end{abstract}

Keywords Cape vulture, dispersal, Endangered, Gyps coprotheres, kernel density, protected areas, southern Africa, spatial ecology

BEN JoBson ${ }^{*}$ (Corresponding author, (1) orcid.org/0000-0001-6131-1476) Imperial College London, Silwood Park, Berkshire, SL5 7PY, UK

E-mail ben.jobson@birdlife.org

Kerri Wolter and Lara Jordan VulPro, Rietfontein, Hartbeespoort Dam, North West Province, South Africa

ARA Monadjem Department of Biological Sciences, University of Eswatini, Kwaluseni, Eswatini, and Department of Zoology and Entomology, Mammal Research Institute, University of Pretoria, Pretoria, South Africa

J. Marcus Rowcliffe Zoological Society of London, Institute of Zoology, London, UK

${ }^{*}$ Present address: BirdLife International, The David Attenborough Building, Pembroke Street, Cambridge, CB2 3QZ, UK

Received 21 December 2018. Revision requested 13 February 2019.

Accepted 18 June 2019. First published online 4 September 2020.

\section{Introduction}

The African vulture crisis has seen Gyps species follow1 ing global trends of declines caused by a combination of threats, including persecution, reduced food availability, poisoning and electrocution on powerlines (Ogada et al., 2012, 2016). The Cape vulture Gyps coprotheres is categorized as Endangered on the IUCN Red List (BirdLife International, 2017) and its life history strategy, characterized by long generation times (Mundy et al., 1992), makes colonies susceptible to declines (Piper et al., 1989).

Vultures provide significant ecosystem services, including the removal of carcasses, nutrient recycling and reducing the transmission of diseases (Markandya et al., 2008; Ogada et al., 2012; López-López et al., 2014). Declines in vulture populations can be self-reinforcing through the Allee effect, as populations rely on social information to enhance foraging efficiency (Jackson et al., 2008). Reinforcement of populations at declining colonies is preferable to full reintroduction projects and this is particularly pertinent for vultures, as Allee effects are likely to limit the effectiveness of re-establishment efforts and the persistence of small colonies (Le Gouar et al., 2008; Armstrong \& Wittmer, 2011).

Rehabilitation is an often practiced but poorly monitored intervention for raptors (Monadjem et al., 2014), which may enhance population growth during early stages of species recovery (Steven et al., 1997). For example, release of rehabilitated Cape vultures can buffer the effects of colony declines, as long as the proportion of rehabilitated birds in the population does not exceed 50\% (Monadjem et al., 2014). Captive-bred Gyps vultures have been successfully reintroduced in Europe (Sarrazin et al., 1994).

Here we examine, for the first time, the movement ecology of captive-bred and rehabilitated Cape vultures, and compare this with available data for wild birds (Bamford et al., 2007; Phipps et al., 2013; Pfeiffer et al., 2015; Kane et al., 2016). Comparisons between captive-bred and rehabilitated groups are apt, as both groups could develop behavioural aberrations during their time in anthropogenic care that cause them to differ from their wild counterparts. Juvenile dispersal presents a challenge for translocations as dispersing vultures may leave colonies targeted for reinforcement. We aim to provide insight into the preliminary stages of the post-release spatial ecology of translocated Cape vultures, and to identify any similarities and 
differences in home range size, patterns of habitat selection and protected area usage between captive-bred and rehabilitated individuals. We predict that there are no differences between the two groups, as they are expected to exhibit the same innate patterns of spatial ecology.

\section{Species and study area}

Juvenile Cape vultures are known to disperse far from their natal colony and forage in home ranges an order of magnitude greater than those of adults, which demonstrate colony fidelity (Bamford et al., 2007). All individuals in this study were released in the core of their distribution along the Magaliesberg Mountain range at Nooitgedacht colony in Gauteng and North West Provinces, South Africa (Fig. 1). This ridgeline, at $1,852 \mathrm{~m}$ altitude, is protected under UNESCO's World Biosphere Reserve Programme and straddles the boundary between the Bushveld vegetation to the north and Highveld grasslands to the south. This region holds two breeding cliffs (Nooitgedacht and Skeerpoort) and previously held the now extinct colony at Robert's Farm (Wolter et al., 2007).

\section{Methods}

\section{Data collection}

We analysed the movements of 20 captive-bred and 13 rehabilitated Cape vultures, of all age classes. Rehabilitated vultures were wild birds that had sustained treatable ailments, such as fractures or emaciation, and originated from across northern South Africa (Naidoo et al., 2011). Age classes were fledgling (o-8 months), juvenile ( 9 months3 years), immature (4-5 years), subadult (6-7 years) and adult ( $>7$ years) (Piper et al., 1989). Vultures were fitted with GPS-Global System for Mobile Communications trackers, attached with a Teflon backpack-style harness within plastic tubing, to reduce potential friction (Wolter et al., 2018). Before release, birds were subject to a variable period of acclimation ( $<6$ months) within a predator-proof enclosure at the release site. We collated tracking data that were logged during 2015-2018 from devices transmitting at a minimum rate of once every 6 hours and a maximum of every 2 minutes. Birds were tracked for a mean duration of $518 \pm$ SE 59 days. We standardized data by selecting three random points to retain per tracking day, to account for varying transmission rates and minimize spatial autocorrelation.

\section{Home range analysis}

We initially calculated the asymptote of home range size to determine whether home ranges of birds were still expanding at the time of this study (Steiniger \& Hunter,

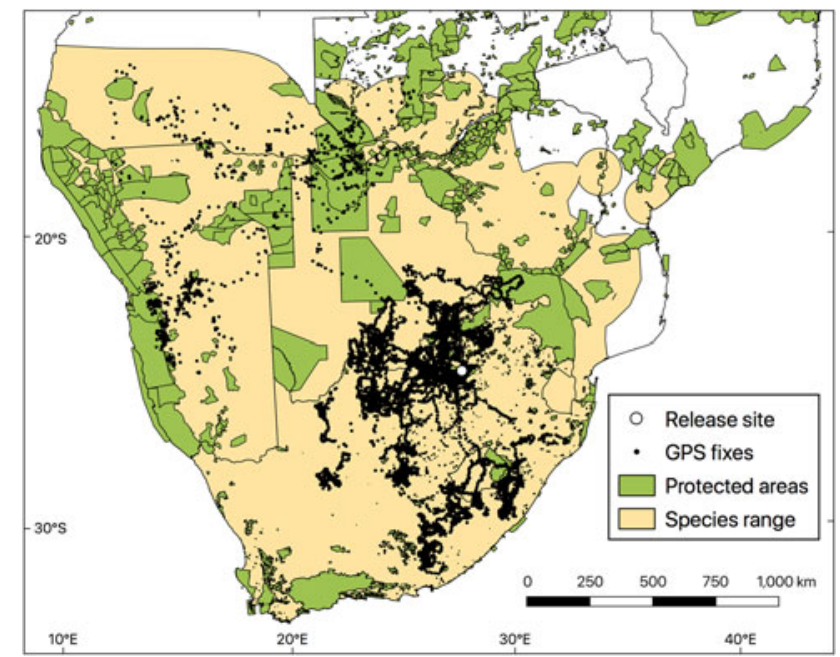

FIG. 1 The locations of Cape vulture Gyps coprotheres GPS fixes, their release site, protected areas, and the IUCN Red List range of the species (BirdLife, 2017).

2012). Five individuals (two captive-bred and three rehabilitated birds) did not produce asymptotic outputs from this analysis and were excluded from the study. A two-tailed Mann-Whitney test was used to compare the number of GPS points for captive-bred and rehabilitated vultures before they achieved home range stabilization. We carried out home range estimation using $R$ 3.4.2 (R Core Team, 2017) and the $R$ package adehabitat (Calenge, 2006). We used kernel density estimation to calculate the 95 and 50\% contours for overall and core home ranges, respectively. For smoothing of contours, we selected the default reference bandwidth as this is robust against potential outliers in large data sets (Hemson et al., 2005). We used generalized linear models (GLMs) to examine whether overall and core home range are a function of vulture group (rehabilitated or captive-bred), age, injury, sex and time spent in rehabilitation. We $\log _{10}$ transformed home range size to remove a pronounced skew. To identify any differences in the propensity of study birds to disperse long distances we compared correlates of dispersal distance. We examined mean Euclidean dispersal distance between individuals by comparing the distance from the release site to the centroid of each bird's home range with a two-tailed Mann-Whitney test.

\section{Habitat selection}

Habitat selection can be classified into three levels: first order selection identifies a geographical range for a species, second order selection ascertains its home range formation, and third order selection describes an individual's use of habitat within the home range (Johnson et al., 1980). We analysed second order habitat selection type by comparing 
relative numbers of individual vulture GPS fixes in each habitat with the proportion of that habitat in the study area (Manly et al., 2002). Locations were overlaid onto a $20 \mathrm{~m}$ resolution land cover raster file that included the following biome categories: aquatic vegetation/flooded land, bare ground, cropland, grassland, vegetation dominated by lichen and mosses, open water, shrubland, trees and urban (ESA CCI, 2017). Values pertaining to the nine categories were extracted from each location and compared to a layer of randomly generated points. Only cropland, grassland, shrubland and trees were analysed with a generalized linear mixed model (GLMM), as the other five habitats had considerably lower levels of visitation by all vultures (Fig. 2). We used the GLMM to examine whether habitat selection is a function of vulture group, sex, injury, age, time spent in rehabilitation (set as fixed variables), and each bird's unique identifier (as a random variable), fitted to a Poisson distribution, with the lme4 package in $R$ (Bates et al., 2015). We projected GPS location data into Universal Transverse Mercator Zone $35 \mathrm{~S}$ using QGIS 2.18.13 (QGIS Development Team, 2009). We then overlaid all vulture GPS fixes on protected areas across southern Africa (IUCN \& UNEP-WCMC, 2016). We used the intersection tool in QGIS to calculate protected areas available to the vultures as the intersection between a 95\% local convex hull polygon for each bird and the protected area shapefile. For each bird, we generated an
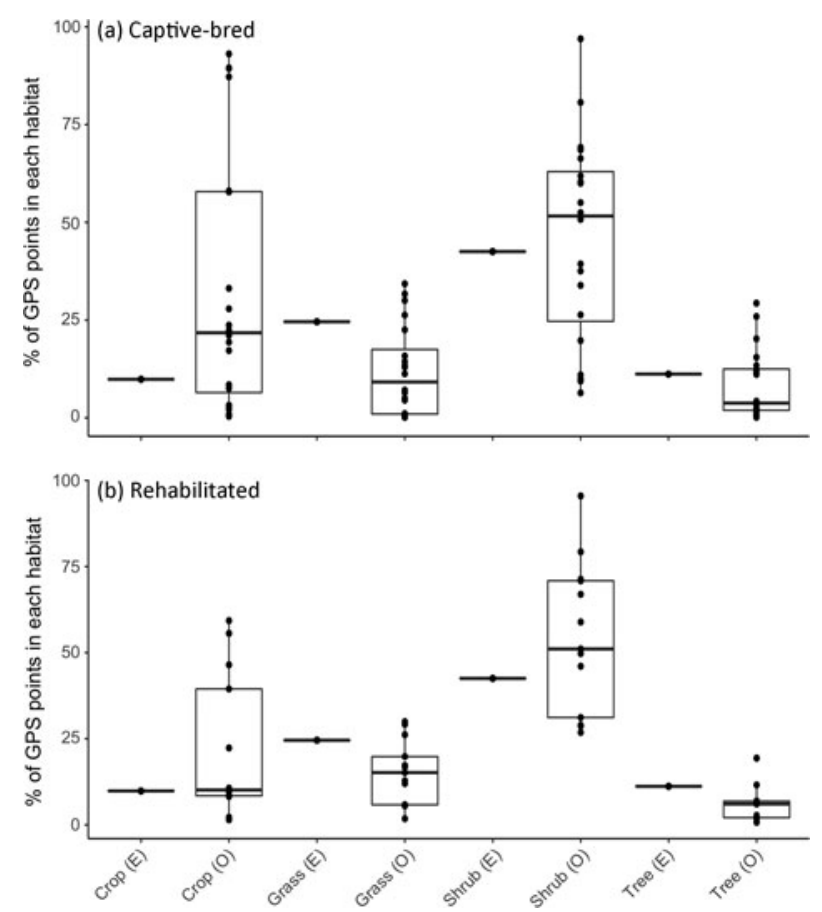

FIG. 2 Box plots of the per cent of GPS fixes in each habitat for individual (a) captive-bred and (b) rehabilitated Cape vultures observed (O) and expected (E) habitat use for the four most used habitats (crop, grass, shrub and tree). Expected habitat use was calculated from the same number of locations randomly generated, to simulate non-selective foraging. equivalent number of GPS fixes to those recorded and randomly distributed them across its range (95\% local convex hull polygon). We then compared the per cent of actual GPS fixes falling within protected areas (observed visitation) with the percentage of randomly generated fixes within protected areas for each individual (expected visitation). We used the $\chi^{2}$ test to determine whether there was any significant deviation between observed and expected points. Subsequently, we compared levels of protected area visitation between captive-bred and rehabilitated vulture groups, with a t test.

\section{Results}

\section{Home range}

We analysed 253,671 GPS fixes, revealing that vultures navigated across eight southern African countries and established home ranges that spanned six orders of magnitude from $<_{1} \mathrm{~km}^{2}$ to $2,022,465 \mathrm{~km}^{2}$ (mean $162,824 \pm \mathrm{SE} 65,096$ $\mathrm{km}^{2}$ ). One rehabilitated bird traversed seven countries and thereby substantially increased the known distance travelled by an individual Cape vulture. Mean home range size differed between captive-bred (mean 61,629 $\pm \mathrm{SE} 24,942 \mathrm{~km}^{2}$ ) and rehabilitated birds (mean $318,510 \pm \mathrm{SE} 154,390 \mathrm{~km}^{2}$; Table 1). However, the GLM showed that the estimates of kernel density utilization for the overall (95\%) and core (50\%) home ranges were not significantly different between groups. The estimated home range size of rehabilitated and captive-bred birds were similar to that of wild Cape vultures, although estimates for captive-bred birds were closer to the smaller home range estimates for wild adult birds (Table 2). Core home range was closer to the release site for captivebred than for rehabilitated vultures. The Mann-Whitney test showed greater linear dispersal of rehabilitated birds from their release site (mean 227.08 \pm SE $53.60 \mathrm{~km}$ ) than by captive-bred birds (mean $82.80 \pm S E 24.82 \mathrm{~km}$; $Z=-2.744, \mathrm{P}=0.006$.) Additionally, there were no significant effects of age, sex, or time spent in rehabilitation on home range size.

\section{Habitat selection}

Our analysis showed that captive-bred and rehabilitated Cape vultures selected the same habitat types across the landscape and the GLMM confirmed there were no statistical differences between the groups. Both groups showed positive selection, when compared with random points, for cropland and shrubland, but visited grassland and trees less than expected (Fig. 2). Additionally, the GLMM did not show any significant effects of sex, injury, age or time spent in rehabilitation on habitat selection. The $\chi^{2}$ test showed that observed visitation of protected areas was significantly higher than expected for all birds 
TABLE 1 Details of the 20 captive-bred and 13 rehabilitated Cape vultures Gyps coprotheres, with sex and type of injury, overall and core home ranges (95 and 50\% kernel density estimates, respectively) and the total number of fixes and standardized fixes (after taking only three points per bird, per day).

\begin{tabular}{|c|c|c|c|c|c|c|}
\hline \multirow[b]{2}{*}{ ID } & \multirow[b]{2}{*}{$\operatorname{Sex}^{1}$} & \multirow[b]{2}{*}{ Injury } & \multicolumn{2}{|l|}{ Home range $\left(\mathrm{km}^{2}\right)$} & \multirow{2}{*}{$\begin{array}{l}\text { Total no. } \\
\text { of fixes }\end{array}$} & \multirow{2}{*}{$\begin{array}{l}\text { Total no. of } \\
\text { standardized fixes }\end{array}$} \\
\hline & & & $95 \%$ & $50 \%$ & & \\
\hline \multicolumn{7}{|c|}{ Captive-bred } \\
\hline $\mathrm{CV} 1$ & $\mathrm{~F}$ & None & 4.75 & $<1$ & 10,347 & 513 \\
\hline $\mathrm{CV} 2$ & $\mathrm{M}$ & None & 4.02 & $<1$ & 4,623 & 87 \\
\hline CV3 & $\mathrm{F}$ & None & $<1$ & $<1$ & 14,922 & 1,134 \\
\hline CV4 & $\mathrm{F}$ & None & 2.41 & $<1$ & 29,143 & 369 \\
\hline CV5 & $\mathrm{F}$ & None & 6,635 & 897 & 11,629 & 516 \\
\hline CV6 & $\mathrm{F}$ & None & 101,473 & 13,688 & 3,546 & 138 \\
\hline CV7 & M & None & $<1$ & $<1$ & 1,012 & 438 \\
\hline CV8 & $\mathrm{M}$ & None & 273,569 & 77,502 & 9,291 & 459 \\
\hline CV9 & $\mathrm{M}$ & None & 36,259 & 5,176 & 1,049 & 57 \\
\hline CV10 & $\mathrm{M}$ & None & $<1$ & $<1$ & 1,973 & 762 \\
\hline CV11 & $\mathrm{M}$ & None & 5,386 & 817 & 6,465 & 177 \\
\hline CV12 & $\mathrm{F}$ & None & 270,962 & 41,052 & 32,461 & 660 \\
\hline CV13 & M & None & 4.84 & $<1$ & 13,977 & 270 \\
\hline CV14 & $\mathrm{F}$ & None & 12,782 & 2,678 & 1,722 & 96 \\
\hline CV15 & $\mathrm{M}$ & None & 507 & 82 & 2,033 & 459 \\
\hline CV16 & $\mathrm{M}$ & None & 102,189 & 23,678 & 9,246 & 701 \\
\hline CV17 & $\mathrm{F}$ & None & 3,858 & 637 & 1,174 & 135 \\
\hline CV18 & $\mathrm{M}$ & None & 44,833 & 12,643 & 934 & 115 \\
\hline CV19 & $\mathrm{M}$ & None & 230 & 37 & 708 & 81 \\
\hline CV20 & $\mathrm{F}$ & None & 373,876 & 87,610 & 554 & 102 \\
\hline$M e a n \pm S E$ & & & $61,629 \pm 24,942$ & $13,323 \pm 5,795$ & & \\
\hline \multicolumn{7}{|c|}{ Rehabilitated } \\
\hline RH1 & $\mathrm{F}$ & Emaciated & $2,022,465$ & 455,844 & 8,372 & 3,109 \\
\hline RH2 & M & Bee stings & 470 & 74 & 993 & 120 \\
\hline RH3 & $\mathrm{M}$ & Leg fracture & 201,791 & 36,044 & 35,741 & 435 \\
\hline RH4 & $\mathrm{F}$ & Emaciated & 3,155 & 515 & 6,287 & 141 \\
\hline RH5 & $\mathrm{M}$ & Emaciated & 4,297 & 425 & 7,311 & 222 \\
\hline RH6 & $\mathrm{F}$ & Wing fracture & 215,045 & 42,189 & 2,419 & 408 \\
\hline RH7 & $\mathrm{F}$ & Burn & 812,755 & 219,342 & 2,895 & 303 \\
\hline RH8 & $\mathrm{F}$ & Emaciated & 36,709 & 4,592 & 8,978 & 1,026 \\
\hline RH9 & $\mathrm{F}$ & Emaciated & 282,229 & 66,849 & 2,052 & 206 \\
\hline RH10 & $\mathrm{F}$ & Emaciated & 3 & $<1$ & 1,967 & 99 \\
\hline RH11 & $\mathrm{F}$ & Emaciated & 95,238 & 15,675 & 7,688 & 684 \\
\hline RH12 & $\mathrm{F}$ & Wing fracture & 248,647 & 54,390 & 10,932 & 714 \\
\hline RH13 & $\mathrm{F}$ & Unknown & 217,820 & 49,096 & 1,227 & 123 \\
\hline$M e a n \pm S E$ & & & $318,510 \pm 154,390$ & $72,695 \pm 35,841$ & & \\
\hline
\end{tabular}

${ }^{1} \mathrm{~F}$, female; $\mathrm{M}$, male.

TABLE 2 Home range size of immature and adult Cape vultures estimated in four previous studies.

\begin{tabular}{lll}
\hline Immatures $\left(\mathrm{km}^{2}\right)$ & Adults $\left(\mathrm{km}^{2}\right)$ & Source \\
\hline 482,276 & 21,320 & Bamford et al. (2007) \\
492,300 & 121,655 & Phipps et al. (2013) \\
295,379 & 110,181 & Kane et al. (2016) \\
287,199 & & Martens et al. (2018) \\
\hline
\end{tabular}

$\left(\chi^{2}=1,140.2, \mathrm{df}=34, \mathrm{P}=<0.01\right)$. Captive-bred vultures had a higher per cent of GPS fixes within protected areas (mean $75.88 \pm$ SE 6.51\%) than rehabilitated vultures (mean $50.63 \pm$ SE 9.98\%; $\left.t_{24}=2.12, \mathrm{P}=0.04\right)$.

\section{Discussion}

Our analysis of GPS tracking data for Cape vultures released from a captive breeding and rehabilitation centre supported our prediction that the two groups had similar home range sizes and habitat selection. However, comparison with entirely wild birds is required, to examine whether captive-bred and rehabilitated birds can integrate fully with the wild population. The main difference between captive-bred and rehabilitated vultures was the reduced level of dispersal from the release site by captive-bred vultures, possibly the result of supplementary feeding near 
the release site. In the wild, vultures have not been shown to alter their foraging behaviour as a result of the presence of these so-called vulture restaurants but there may be an effect on captive-bred birds that have experienced food provisioning throughout their lives (Kane et al., 2016). Predictability of food availability is an important factor in shaping the home ranges of other vulture species and could play a role in the behaviour of released Cape vultures (López-López et al., 2014). Food and water provisioning in protected areas, as well as the continual mitigation of threats across the species distribution, are likely to provide significant benefits to both rehabilitated and captive-bred birds. Because captive-bred birds have home ranges closer to the release site, their scavenging ecosystem service will probably be reduced in other parts of their range. An important question arising from our study is whether captive-bred birds are likely to settle at distant colonies: this would have implications for gene flow and heterozygosity. As our study indicates that captive-bred Cape vultures may be less likely to disperse from their release site, it is important to continue analyses of these birds as they age and, ideally, to refit them with new GPS devices when the current ones stop transmitting, to obtain additional longitudinal data.

The size of Cape vulture home ranges in this study was more variable than reported in studies of wild birds (Phipps et al., 2013; Pfeiffer et al., 2015; Kane et al., 2016). There were a few unusually small home ranges, which resulted from some birds feeding regularly at the vulture restaurant, remaining near the release site and roosting on the enclosures of the captive-breeding colony. An additional question arising from our study is whether these captive-bred birds have the behavioural flexibility to learn from conspecifics, and hence extend their home ranges over time. We did not detect a difference between adult and juvenile home ranges, something other studies have identified (Bamford et al., 2007; Phipps et al., 2013; Krüger et al., 2014). However, the relatively small sample sizes, especially within the rehabilitated group, may have precluded determination of a clear effect of age.

Rehabilitated birds may have individual differences in personality that originally caused them to sustain injuries and likewise influenced their spatial ecology. Individual variability in spatial ecology has been identified in raptors, and although we controlled for individuality within the GLMM, the rehabilitated study group may have comprised birds prone to injury as a result of their personalities (Campioni et al., 2013). Our habitat selection analyses suggest that foraging is an innate capability retained by captive-bred birds, as they demonstrated movement through the same suitable habitat types as rehabilitated birds. In light of significant declines in natural food sources, the ability to forage in the most appropriate environments may increase the chances of survival for translocated birds (Botha et al., 2017).
The expectation that there would be equal usage of protected areas between the two groups of vultures was not met, with captive-bred birds visiting protected areas more than rehabilitated birds. However, both groups visited protected areas significantly more than predicted based on random movement (Phipps et al., 2013). The apparent preference for protected areas may be explained by our release site being situated within a protected area and the presence of consistent supplementary feeding. Additionally, by releasing captive-bred birds within protected areas, it is likely they will form home ranges closer to these locations and receive the protection conferred by these sites.

The inherent nomadism of vultures and the ranging capabilities highlighted in this study provide support for the ongoing prioritization of vulture conservation across southern Africa. That captive-bred vultures maintain innate capabilities to range in a way that is largely indistinguishable from that of formerly wild rehabilitated birds supports continued captive breeding. Future long-term studies should seek to analyse survivorship and identify the breeding behaviour of captive-bred birds once they reach sexual maturity.

Acknowledgements We acknowledge the following VulPro sponsors who contributed to rehabilitation, breeding, feeding, veterinary care, research and monitoring of the birds in this study, and provided financial support: Bayer SA, Banham Zoo, Birmingham Zoo (Alabama), Blair Drummond Safari Park, BoehringerIngelheim, Boikarabelo Coal Mine, Cellular Tracking Technologies, Chicago Board of Trade Endangered Species Fund, Cheyenne Mountain Zoo, Cleveland Metroparks Zoo and Cleveland Zoological Society, Columbus Zoo, Colchester Zoo, Dallas Zoo, DHL Supply Chain, Gauntlet Conservation Trust, GH Braak Trust, Hans Hoheisen Charitable Trust, International Centre for Birds of Prey, Jacksonville Zoo and Gardens, Lomas Wildlife Protection Trust, LUSH Cosmetics, Martin Moore of the Moore Foundation, MaxPlanck-Gesellschaft, Monte Casino Bird Gardens, Natural Encounters Inc., Prince Bernhard Nature Fund, Rand Merchant Bank, Riverbanks Zoo and Garden, Rudi Wolter with Copper Sunset Sands Pty. Ltd, Sacramento Zoo, The Hawking Centre UK, The Tusk Trust, SW Living Creatures Trust, ZKTeco and Zoo Atlanta-Reeder Conservation Fund. We thank Ewan Flintham for his support.

Author contributions Study design and review: all authors; GPS tracking and fieldwork: BJ, KW, LJ; data analysis and writing: BJ; revision: all authors.

\section{Conflicts of interest None.}

Ethical standards Research was approved by Imperial College Research Ethics Committee and permits issued by Gauteng covered the keeping (002619) and transportation (02889) of vultures, and otherwise abided by the Oryx guidelines on ethical standards. Risk of disease transmission is deemed naturally low for vulture species, as they have evolved to withstand otherwise contagious diseases and are often highly resistant. Our population reinforcement project was categorized as a least-risk, least-regret translocation using IUCN/ Species Survival Commission terminology. All relevant risk categories outlined by IUCN/Species Survival Commission were evaluated as having low/no risk. 


\section{References}

Armstrong, D.P. \& Wittmer, H.U. (2011) Incorporating Allee effects into reintroduction strategies. Ecological Research, 26, 687-695.

Bamford, A.J., Diekmann, M., Monadjem, A. \& Mendelsohn, J. (2007) Ranging behaviour of Cape vultures Gyps coprotheres from an endangered population in Namibia. Bird Conservation International, 17, 331-339.

Bates, D., Mächler, M., Bolker, B. \& Walker, S. (2015) Fitting linear mixed-effects models using lme4. Journal of Statistical Software, 67, 1-48.

Birdife International (2017) Gyps coprotheres (amended version of 2016 assessment). In The IUCN Red List of Threatened Species 2017: e.T22695225A118592987. dx.doi.org/10.2305/IUCN.UK.2017-3. RLTS.T22695225A118592987.en [accessed 28 May 2018].

Botha, A.J., Andevski, J., Bowden, C.G.R., Gudka, M., Tavares, J., Safford, R.J. \& Williams, N.P. (2017) Multi-Species Action Plan to Conserve African-Eurasian Vultures. Raptors MoU Technical Publication No. 4. CMS Technical Series No. 33. Coordinating Unit of the CMS Raptors MoU, Abu Dhabi, United Arab Emirates.

Calenge, C. (2006) The package 'adehabitat' for the $R$ software: a tool for the analysis of space and habitat use by animals. Ecological Modelling, 197, 1035.

Campioni, L., Del Mar Delgado, M., Lourenço, R., Bastianelli, G., Fernández, N. \& Penteriani, V. (2013) Individual and spatio-temporal variations in the home range behaviour of a long-lived, territorial species. Oecologia, 172, 371-385.

ESA CCI (2017) S2 Prototype Land Cover 20 m Map of Africa 2016. 2016africalandcover20 m.esrin.esa.int [accessed 27 July 2018].

Hemson, G., Johnson, P., South, A., Kenward, R., Ripley, R. \& Macdonald, D. (2005) Are kernels the mustard? Data from global positioning system (GPS) collars suggests problems for kernel home-range analyses with least-squares cross-validation. Journal of Animal Ecology, 74, 455-463.

IUCN \& UNEP-WCMC (2016) The World Database on Protected Areas. UNEP-WCMC, Cambridge, UK. protectedplanet.net [accessed 3 June 2018].

Jackson, A.L., Ruxton, G.D. \& Houston, D.C. (2008) The effect of social facilitation on foraging success in vultures: a modelling study. Biology Letters, 4, 311-313.

Johnson, D.H. (1980) The comparison of usage and availability measurements for evaluations of resource preference. Ecology, $61,65-71$.

Kane, A., Wolter, K., Neser, W., Kotze, A., Naidoo, V. \& Monadjem, A. (2016) Home range and habitat selection of Cape vultures Gyps coprotheres in relation to supplementary feeding. Bird Study, 63, 387-394.

KRUGGer, S., Reid, T. \& Amar, A. (2014) Differential range use between age classes of southern African bearded vultures Gypaetus barbatus. PLOS ONE, 9, e114920.

Le Gouar, P., Robert, A., Choisy, J.-P., Henriquet, S., Lecuyer, P., Tessier, C. \& Sarrazin, F. (2008) Roles of survival and dispersal in reintroduction success of Griffon vulture (Gyps fulvus). Ecological Applications, 18, 859-872.

López-López, A.P., García-Ripollés, C. \& Urios, V. (2014) Food predictability determines space use of endangered vultures: implications for management of supplementary feeding. Ecological Applications, 24, 938-949.
Manly, B.F., McDonald, L., Thomas, D., McDonald, T.L. \& ERICKSON, W.P. (2002) Resource Selection by Animals: Statistical Design and Analysis for Field Studies. Kluwer Publishers, Boston, USA.

Markandya, A., Taylor, T., Longo, A., Murty, M.N., Murty, S. \& Dhavala, K. (2008) Counting the cost of vulture decline-An appraisal of the human health and other benefits of vultures in India. Ecological Economics, 67, 194-204.

Martens, F.R., Pfeiffer, M.B., Downs, C.T. \& Venter, J.A. (2018) Post-fledging movement and spatial ecology of the Endangered Cape vulture (Gyps coprotheres). Journal of Ornithology, 159, 913-922.

Monadjem, A., Wolter, K., Neser, W. \& Kane, A. (2014) Effect of rehabilitation on survival rates of Endangered Cape vultures. Animal Conservation, 17, 52-60.

Mundy, P.J., Peter J., Butchart, D. \& Vulture Study Group (1992) The Vultures of Africa. Academic Press, London, UK.

Naidoo, V., Wolter, K., Espie, I. \& Kotze, A. (2011) Vulture rescue and rehabilitation in South Africa: an urban perspective. Journal of the South African Veterinary Association, 82, 24-31.

Ogada, D., Keesing, F. \& Virani, M. (2012) Dropping dead: causes and consequences of vulture population declines worldwide. Annals of the New York Academy of Sciences, 1249, 57-71.

Ogada, D., Shaw, P., Beyers, R.L., Buij, R., Murn, C., Thiollay, J.M. et al. (2016) Another continental vulture crisis: Africa's vultures collapsing toward extinction. Conservation Letters, 9, 89-97.

Pfeiffer, M.B., Venter, J.A. \& Downs, C.T. (2015) Foraging range and habitat use by Cape vulture Gyps coprotheres from the Msikaba colony, Eastern Cape province, South Africa. Koedoe, 57, 1-11.

Phipps, W.L., Wolter, K., Michael, M.D., MacTavish, L.M. \& YARNELL, R.W. (2013) Do power lines and protected areas present a catch-22 situation for cape vultures (Gyps coprotheres)? PLOS ONE, 8, e76794.

Piper, S.E., Mundy, P.J. \& Vernon, C.J. (1989) An ageing guide for the Cape vulture. Madoqua, 2, 105-110.

QGiS Development Team (2009) QGIS Geographic Information System. Open Source Geospatial Foundation. qgis.org/en/site/index. html [accessed 10 May 2018].

R Core Team (2017) R: A Language and Environment for Statistical Computing. Foundation for Statistical Computing, Vienna, Austria. r-project.org [accessed 31 May 2018].

Sarrazin, F., Bagnolini, C., Pinna, J.L., Danchin, E. \& Bullet, J.C. (1994) High survival estimates of griffon vultures (Gyps fulvus fulvus) in a reintroduced population. The Auk, 111, 853-862.

Steiniger, S. \& Hunter, A.J.S. (2012) OpenJUMP HoRAE-A free GIS and toolbox for home-range analysis. Wildlife Society Bulletin, $36,600-608$.

Steven, U.S., Sweeney, J., Redig, P.T. \& Tordoff, H.B. (1997) Morbidity, survival and productivity of rehabilitated peregrine falcon in the Upper Midwestern. Journal of Raptor Research, $31,347-35$.

Wolter, K., Neser, W. \& Hirschauer, M.T. (2018) Protocols for mass capturing, handling, and fitting tracking devices and patagial (wing) tags on vultures. VulPro NPC, Scheerpoort, South Africa.

Wolter, K., Whittington-Jones, C. \& West, S. (2007) Status of cape vultures (Gyps coprotheres) in the Magaliesberg, South Africa. Vulture News, 57, 24-31. 